\title{
Somaclonal variation for disease resistance in wheat and production of dihaploids through wheat $\mathrm{x}$ maize hybrids
}

\author{
Yeshwant R. Mehtal and Dilma C. Angra ${ }^{2}$
}

\begin{abstract}
Seven wheat cultivars having some degree of resistance to Bipolaris sorokiniana, Magnaporthe grisea or Xanthomonas campestris pv. undulosa $(\mathrm{Xcu})$ provided somaclonal variation for disease resistance. Callus induction varied from 69.4 to $100 \%$ across the cultivars, whereas regeneration frequency of R1 plants (regenerated plants of first generation) varied between 2.7 and $23.1 \%$. Resistance variation in the R2-regenerated second generation plants was observed for B. sorokiniana and M. grisea but not for Xcu. Attempts were made to fix the resistance characteristics of R3-regenerated third generation somaclones through wheat $\mathrm{x}$ maize hybrids. Wheat and maize hybridization of seven wheat somaclones yielded 81 embryos. A total of 11,624 somaclone florets were pollinated, of which $8.4 \%$ produced haploid embryos across the seven wheat genotypes. Hybrid embryo production varied between 0 and $25 \%$. The somaclones had a constant chromosome number as observed in their original hexaploid wheat genotypes $(2 \mathrm{n}=6 \mathrm{x}=42)$ whereas the haploid plants had $\mathrm{n}=21$. Hybrid embryo production and haploid and dihaploid plant production were affected by 2,4-D concentration, but not by the wheat genotype.
\end{abstract}

\section{INTRODUCTION}

Most Brazilian wheat cultivars have a high yield potential but are susceptible to several diseases such as spot blotch, caused by Bipolaris sorokiniana; blast, caused by Magnaporthe grisea, and bacterial leaf stripe, caused by Xanthomonas campestris pv. undulosa (Xcu). It is believed that resistance to spot blotch and bacterial stripe is governed by polygenes. Although sources of resistance are continually being identified (Mehta, 1981, 1996a; Mehta et al., 1996), the degree of resistance of commercial varieties is inadequate. Breeding efforts to transfer resistance from such sources have received top priority during the past two decades, nonetheless, results are discouraging, partly because of the polygenic nature of resistance and partly because of a lack of ample genetic diversity among resistance sources.

The production of wheat haploids via chromosome elimination is one of the latest and most useful techniques in gene transfer experiments (Laurie and Bennett, 1988; Riera-Lizarazu and Mujeeb-Kazi, 1990; Riera-Lizarazu et al., 1992; Zhang et al., 1996). Production of haploid wheat plants and subsequent production of dihaploids (double haploids) can fix desirable characters in a single generation. Utilizing the somaclonal variation technique (Vasil and Vasil, 1986), attempts have been made to obtain variation in resistance to B. sorokiniana, M. grisea and Xcu, without drastically altering positive agronomic characteristics of the original genotypes. Our study was aimed at fixing resistance characters of the somaclones by producing haploids and dihaploids through wheat and maize hybridization.

\section{MATERIAL AND METHODS}

\section{Regeneration of somaclonal plants}

Success in callus induction and regeneration of somaclonal plants that are resistant to different diseases is obtained by utilizing explants of genotypes that already possess some degree of resistance (Maddock et al., 1983). The wheat cultivars 'Batuira', 'IAPAR 53', 'IAPAR 40', 'OCEPAR 14', 'OCEPAR 17', 'OCEPAR 19' and 'BR 18', are some of the most popular cultivars in the State of Paraná, Brazil. Since these cultivars were reported to have some degree of resistance to one or the other aforementioned pathogens (Mehta, 1981, 1996a; Mehta et al., 1996), they were selected for somaclonal variation. Seeds obtained from the IAPAR germplasm collection were selected from a typical spike of each wheat cultivar, multiplied by selfing once, then stored for further use.

Fifteen to 20 plants of each cultivar were planted in a glasshouse on three sowing dates separated by a 7-day interval. The floral primordia of these plants in their very initial developmental stages (inflorescences $0.5-2.0 \mathrm{~cm}$ in length) were selected for callus induction and regeneration of somaclonal plants, using Petri plates containing $10 \mathrm{ml}$ MS (Murashige and Skoog), callus induction medium (Murashige and Skoog, 1962), with $2.0 \mathrm{mg}$ 2,4$\mathrm{D} / \mathrm{l}$. Immature inflorescences were surface sterilized in $40 \%$ sodium hypochlorite solution, excised into small pieces of up to 2-3 mm, placed on Petri plates containing callus induction medium and incubated in the dark for 30 days at $26^{\circ} \mathrm{C}$. After 30 days, the calli were transferred onto 
fresh medium for 15 days under similar incubation conditions. After 45 days, the calli were transferred to a regeneration MS medium (without 2,4-D, but supplemented with $27.8 \mathrm{mg} / \mathrm{l} \mathrm{FeSO}{ }_{4} .4 \mathrm{H}_{2} \mathrm{O}, 37.3 \mathrm{mg} / \mathrm{l} \mathrm{Na}{ }_{2}$-EDTA, $0.5 \mathrm{mg} / \mathrm{l}$ ANA and $3.0 \mathrm{mg} / \mathrm{l}$ kinetin) and incubated at $26^{\circ} \mathrm{C}$ in an 8/16-h dark/light cycle (Araujo et al., 1995). After reaching the three-leaf stage, the regenerated seedlings were climatized by flooding the plates with water and incubated at room temperature for $24 \mathrm{~h}$, followed by transfer to a growth chamber in earthen pots, $20 \mathrm{~cm}$ in diameter, containing soil and organic manure. After 30 days pots were fertilized with 4:30:10 N, $\mathrm{P}_{2} \mathrm{O}_{5}$ and $\mathrm{K}(2.5 \mathrm{~g} / \mathrm{pot})$, and the plants grown to maturity.

Inoculation and evaluation of somaclonal plants for disease resistance

Cultures of B. sorokiniana, M. grisea and Xcu were grown on potato dextrose, oat-meal and nutrient agar (Mehta, 1996a), respectively. Cultures were started one week before inoculation for fungal pathogens and $48 \mathrm{~h}$ before inoculation for the bacterial pathogen, on Petri plates containing the respective media. After growth, plates were flooded with distilled water and gently scraped; the resulting suspension was filtered through two layers of sterile cheese cloth. The conidial concentration was adjusted to $3.0 \times 10^{4}$ conidia/ml and bacterial suspension adjusted to $10^{8} \mathrm{cfu}$ (colony-forming units) $/ \mathrm{ml}$, by diluting with water. One drop of Tween 20 per $200 \mathrm{ml}$ suspension was added and the suspension was sprayed onto the plants using a small atomizer and pressure pump. Inoculations were started on two leaves of 30-day old plants and each pathogen was inoculated at 10-day intervals using separate leaves of each plant. The leaves were first washed with distilled water, gently rubbed between the fingers, and each one held upright and given a quick single round of spray, from top to bottom and back again. Inoculations of R2 plants (regenerated second generation somaclones) were made using: 1) a mixture of seven aggressive monosporic isolates of $B$. sorokiniana obtained from the Instituto Agronômico do Paraná (IAPAR) culture collection (strain Nos.: 9130-9134, 9140 and 9141);2) a mixture of six aggressive isolates of Xcu obtained from the culture collection (strain Nos. 6668, 6712, 6713, 6867, 9217, 9248) (Mehta, 1996a), and 3) one aggressive isolate of $M$. grisea (strain No. 530) from wheat. The inoculated plants were incubated for $16 \mathrm{~h}$ in a completely dark, moist chamber with a water-saturated atmosphere at about $20^{\circ} \mathrm{C}$. Later, these were transferred to another growth chamber set at $20^{\circ} \mathrm{C}$ with about $70 \%$ relative humidity and a 12/12-h dark/light period cycle. Wheat cultivar 'Mitacore' plants, highly susceptible to all three pathogens, were also inoculated and maintained as controls. Leaf area percentage infected (LAI) was calculated 7 days after inoculation by visual estimation using a disease appraisal scale proposed for B. sorokiniana and Xcu (Mehta, 1981, 1996b), where LAI $<1 \%$ was considered resistant. For $M$. grisea, the 0 -1 scale proposed by Zadoks (1972) was used. Disease rating 0 was considered resistant (non-compatible) and 0.25-1.0 as susceptible (compatible) (Prabhu et al., 1992). Resistant plants were grown to maturity.

\section{Production of haploid wheat plants from wheat $\mathrm{x}$ maize crosses}

Attempts were made to fix resistance characteristics of the somaclonal wheat plants of the R3 generation by producing haploid plants from wheat $\mathrm{x}$ maize crosses, following a modified procedure described by Laurie and Bennett (1988). Somaclonal wheat plants were grown in earthen pots in a growth chamber at $20^{\circ} \mathrm{C}$. Spikes of the leading tiller were emasculated 2-3 days before anthesis and covered with glycine bags to avoid cross pollination. After 3-4 days, crosses were made using a mixture of freshly collected pollen from glasshouse-grown maize (Zea mays L.) hybrids 'XL 321' and 'XL 370', produced by BRASKALB, RS, Brazil. These lines are efficient in producing wheat $\mathrm{x}$ maize hybrids (Fernandes, M.I., personal communication). For this purpose, upper and basal spikelets were removed as well as all but primary and secondary florets of the remaining spikelets (Laurie and Bennett, 1988). Maize pollen was dusted on the wheat stigmas using a soft paint brush. Pollinations were then repeated the next day. After pollination, spikes were twice injected with $1 \mathrm{ml} 0.001 \%$ 2,4-D at an interval of $24 \mathrm{~h}, 4$ $5 \mathrm{~cm}$ below the peduncular node. Caryopses were collected from the spikes 13-14 days post-pollination and surfaces sterilized in a 50\% sodium hypochlorite solution for 15 $\mathrm{s}$, followed by rinsing in $75 \%$ ethanol for $1 \mathrm{~min}$. Caryopses were excised aseptically under a stereomicroscope and the rescued embryos transferred to test tubes (with scutella facing upwards) containing regeneration medium without 2,4-D. The embryos were incubated in the dark for 4 days at $5^{\circ} \mathrm{C}$ to break dormancy, and later for 12 days in a growth chamber set at $20^{\circ} \mathrm{C}$. Regenerated plantlets (1-2 leaf stage with good root development) were transferred to pots containing vermiculite and kept covered with a glass beaker in a phytotron at $16^{\circ} \mathrm{C}$, with $12 / 12$-h light/ dark periods. After 7 days the glass beaker was removed, plants were irrigated with nutrient solution and allowed to grow for a few weeks.

After the haploid plants reached the 4-5 tiller stage, their roots were treated for three hours with a solution containing $0.25 \%$ colchicine, then rinsed with distilled water. Colchicine-treated plants of the resistant somaclones were then grown to maturity under the conditions previously mentioned for haploid plant production (Zhang et al., 1996).

Along with the R3 generation somaclones, four elite wheat cultivars 'OCEPAR 16', 'OCEPAR 21', 'OCEPAR 22' and 'IAPAR 60' were also tested for haploid plant production in order to determine whether production of hap- 
loids is wheat-cultivar dependent. Simultaneously, the effects of two concentrations of 2,4-D (0.001 and $0.005 \%)$ on embryo formation was tested using 50 plants per concentration of each of the two arbitrarily selected wheat cultivars 'Batuira' and 'IAPAR 60'.

\section{Cytological analysis of somaclones and their haploids}

Root tips of young seedlings were fixed in 3:1 ethanol acetic acid. After $48 \mathrm{~h}$ in fixative, they were Feulgenstained and examined by light microscopy to determine chromosome numbers (Riera-Lizarazu et al., 1992). Chromosome counts were made on 15-20 original hexaploid somaclones and 15-20 haploid wheat plants originated from wheat $\mathrm{x}$ maize hybrids.

\section{RESULTS AND DISCUSSION}

\section{Production of somaclones}

Callus initiation was observed within 12-15 days and callus induction frequency varied from about $70-100 \%$ depending upon the cultivar (Table I). Floral primordia in their advanced stages $(>3 \mathrm{~cm})$ did not produce calli. Embryogenic calli were compact and yellowish-green. Although no albino or sterile plants were regenerated, abnormal pseudofoliar structures and excessive root development without shoots were observed for some cultivars (Vasil and Vasil, 1986).

Calli were transferred successively to MS regeneration medium without 2,4-D every 30 days. Regeneration frequency of R1 varied and was cultivar dependent (Table I). Resistance against $B$. sorokiniana and $M$. grisea was observed in some R2 plants (Table I), which means that novel resistance genes could be introduced through embryogenesis, which would otherwise be unavailable through conventional breeding methods (De Buyser et al., 1987). None of the somaclonal plants were resistant to Xcu.

Somaclonal variation exists and has been proven to be genetically inherited (Vasil and Vasil, 1986). Success in somaclonal variation is genotype-dependent (Vasil and Vasil, 1986). Though several transformation techniques have been developed, generally speaking such techniques are highly sophisticated and depend on availability of an efficient and reproducible tissue culture system (Jahne et al., 1994). Somaclonal variation, on the other hand, is a relatively simple technique, usable where other methods are not feasible or where resistance genes or genes of interest are not available.

\section{Cytological analysis}

Cytological somaclone analysis gave a constant chromosome number as observed in original hexaploid wheat genotypes $(2 n=6 x=42)$, whereas haploid plants had only half of the number of chromosomes $(n=21)$.

\section{Effect of 2,4-D concentration}

Production of hybrid embryos was not wheat-genotype dependent but depended on the concentration of 2,4-D (Table II). Embryo and haploid plant numbers were severely affected by 2,4-D concentration. The higher 2,4-D concentration resulted in greater embryo and haploid plant numbers in both cultivars. Embryos were also produced when randomly selected wheat cultivars were crossed with maize and the 2,4-D concentration was $0.001 \%$ (Table III). Although embryo frequencies and haploid plant production were much lower when this lower 2,4-D concentration was used (Table IV), the lower concentration is preferred as it avoids further somaclonal/gametoclonal variation (RieraLizarazu et al., 1992), in haploid plant production.

\section{Production of haploids and dihaploides using somaclonal plants}

Wheat and maize hybridization yielded 81 embryos when rescued 13-14 days after pollination. The seeds contained haploid embryos floating in a liquid not characteristic of endosperm (Figure 1). Emasculated and unpollinated florets covered with glycine bags and maintained as con-

Table I - Variation in resistance to Bipolaris sorokiniana (BS)

and Magnaporthe grisea (MG) in wheat plants regenerated through embryogenesis.

\begin{tabular}{|lccccc|}
\hline $\begin{array}{l}\text { Explant (wheat } \\
\text { cultivar) }\end{array}$ & $\begin{array}{c}\text { \% Callus } \\
\text { induction }\end{array}$ & $\begin{array}{c}\text { \%Regeneration } \\
\text { (R1 plants) }\end{array}$ & $\begin{array}{c}\text { No. of R2 } \\
\text { plants }\end{array}$ & $\begin{array}{c}\text { No. of R2 plants } \\
\text { resistant to BS }\end{array}$ & $\begin{array}{c}\text { No. of R2 plants } \\
\text { resistant to } \text { MG }^{\text {c }}\end{array}$ \\
\hline Batuira & 100 & 10 & 93 & 4 & 8 \\
IAPAR 53 & 72.2 & 6.3 & 27 & 1 & 0 \\
IAPAR 40 & 100 & 15.6 & 188 & 3 & 0 \\
OCEPAR 14 & 84.6 & 4.5 & 18 & 3 & 0 \\
OCEPAR 17 & 69.4 & 9.3 & 13 & 2 & 0 \\
OCEPAR 19 & 82.6 & 2.7 & 7 & 7 & 0 \\
BR 18 & 81.3 & 23.1 & 28 & 7 & 0 \\
\hline
\end{tabular}

${ }^{a}$ Calculated in relation to callus induction frequency; ${ }^{b}$ plants with $<15 \%$ leaf area infected were considered resistant; " plants with no infection or with a few brown non-sporulation specks were considered resistant. 
trols revealed no caryopsis or embryos. Of a total of 11,624 florets of somaclonal plants crossed with maize, $8.4 \%$ produced haploid embryos across the seven wheat genotypes (Table IV). Caryopsis formation with or without visible embryos is interpreted as a sign of fertilization. A high fertilization frequency does not necessarily correspond to a high embryo frequency (Comeau et al., 1998). In the case of cv. 'IAPAR 40', for example, percentage of caryopsis production per pollinated florets was about $14.8 \%$, whereas percentage of visible embryos in relation to caryopsis number was only about $10.6 \%$. This is because clusters of some tiny embryo-like structures in the form of calli, lacked a well-defined scutellum, and hence did not produce any hap-

Table II - Effect of 2,4-D concentration on the formation of caryopsis, embryos and haploid plants of two wheat cultivars, using the embryo rescue technique ${ }^{\mathrm{a}}$.

\begin{tabular}{|lrrrrr|}
\hline & \multicolumn{2}{c}{ Cultivar Batuira } & & \multicolumn{2}{c|}{ Cultivar IAPAR 60 } \\
\cline { 2 - 3 } \cline { 5 - 6 } $\begin{array}{l}\text { Concentration } \\
\text { of 2,4-D }(\%)\end{array}$ & 0.001 & 0.005 & & 0.001 & 0.005 \\
\hline No. of pollinated florets & 988 & 1156 & & 980 & 1073 \\
No. of caryopsis & 37 & 469 & & 9 & 292 \\
No. of embryos (\%) & 5 & 62 & & 1 & 90 \\
No. of haploid plants & 1 & 13 & & 0 & 33 \\
\hline
\end{tabular}

a Pollen mixture of maize hybrids XL 321 and XL 370 was used in the wheat crosses. loid plants on the medium even after a prolonged incubation period of 90 days. Some clearly visible embryos also failed to germinate and produced calli. To enhance plant regeneration, Zang et al. (1996) cultured the pre-embryos first in an MS medium containing $2 \mathrm{mg}$ 2,4-D/1 to induce callus and later transferred the calli to a regeneration medium (MS medium supplemented with $2 \mathrm{mg}$ kenetin, 0.5 mg IAA, $0.2 \mathrm{mg}$ 2,4-D, $200 \mathrm{mg}$ glutamine, and $400 \mathrm{mg}$ casein/l) to induce totipotent plant formation. This procedure would undoubtedly increase the probability of somaclonal and/or gametoclonal variation of any kind in dihaploid plants due to mutations provoked by constant use of 2,4-D, i.e., twice in the hybridization process with maize and twice in the callus and the regeneration media. Riera-Lizarazu et al. (1992), used a very high concentration of 2,4-D (100 mg/l) in detached tiller culture. They believed that tissue-culture-associated somaclonal variation could be avoided by polyhaploid production involving wheat $x$ maize hybridization. However, no evidence for this hypothesis has so far been encountered in the literature. We suspect the presence of some somaclonal variation, especially when pre-embryos are forced to produce calli and later to regenerate totipotent plants. As stated earlier, we believe that the lower concentration of 2,4-D $(0.001 \%)$ must have minimized the secondary somaclonal/ gametoclonal variation.

Production percentage of well-developed embryos in relation to number of florets pollinated obtained was some-

Table III - Number of embryos and haploid plants of some wheat cultivars regenerated through embryo rescue technique.

\begin{tabular}{|lccccc|}
\hline $\begin{array}{l}\text { Wheat x maize } \\
\text { hybrid }^{\mathrm{a}}\end{array}$ & $\begin{array}{c}\text { No. of pollinated } \\
\text { florets }\end{array}$ & $\begin{array}{c}\text { Potential No. of } \\
\text { caryopsis }\end{array}$ & $\begin{array}{c}\text { Actual No. of } \\
\text { embryos rescued }\end{array}$ & $\begin{array}{c}\text { \% of embryos } \\
\text { rescued }\end{array}$ & $\begin{array}{c}\text { No. of haploid } \\
\text { plants }\end{array}$ \\
\hline IAPAR 60 & 82 & 19 & 1 & 5.3 & 0 \\
OCEPAR 16 & 690 & 57 & 4 & 7 & 1 \\
OCEPAR 21 & 413 & 68 & 2 & 2.9 & 2 \\
OCEPAR 22 & 1084 & 142 & 10 & 7 & 5 \\
\hline
\end{tabular}

${ }^{a}$ Wheat plants were crossed with mixed pollen of maize hybrids XL 321 and XL 370. 2,4-D was used at a concentration of $0.001 \%$.

Table IV - Number of embryos, haploid and dihaploid somaclonal

plants of some wheat cultivars regenerated through embryo rescue technique.

\begin{tabular}{|lccccc|}
\hline $\begin{array}{l}\text { Wheat x maize } \\
\text { hybrid }^{\text {a }}\end{array}$ & $\begin{array}{c}\text { No. of pollinated } \\
\text { florets }\end{array}$ & $\begin{array}{c}\text { Potential No. of } \\
\text { caryopsis }\end{array}$ & $\begin{array}{c}\text { Actual No. of } \\
\text { embryos }\end{array}$ & $\begin{array}{c}\text { No. of haploid } \\
\text { plants }\end{array}$ & $\begin{array}{c}\text { No. of fertile } \\
\text { dihaploid plants }\end{array}$ \\
\hline Batuira & 3,419 & 181 & 9 & 0 & 0 \\
IAPAR 53 & 844 & 67 & 3 & 2 & 1 \\
IAPAR 40 & 3,283 & 487 & 52 & 24 & 7 \\
OCEPAR 14 & 198 & 24 & 6 & 2 & 1 \\
OCEPAR 17 & 580 & 135 & 1 & 0 & 0 \\
BR 18 & 916 & 4 & 0 & 0 & 1 \\
OCEPAR 19 & 2,384 & 78 & 10 & 2 & 0 \\
\hline
\end{tabular}

a Somaclonal wheat plants of R2 generation were crossed with mixed pollen of maize hybrids XL 321 and XL 370

${ }^{\mathrm{b}} \mathrm{Calculated}$ in relation to the number of embryos rescued. 2,4-D was used at a concentration of $0.001 \%$. 


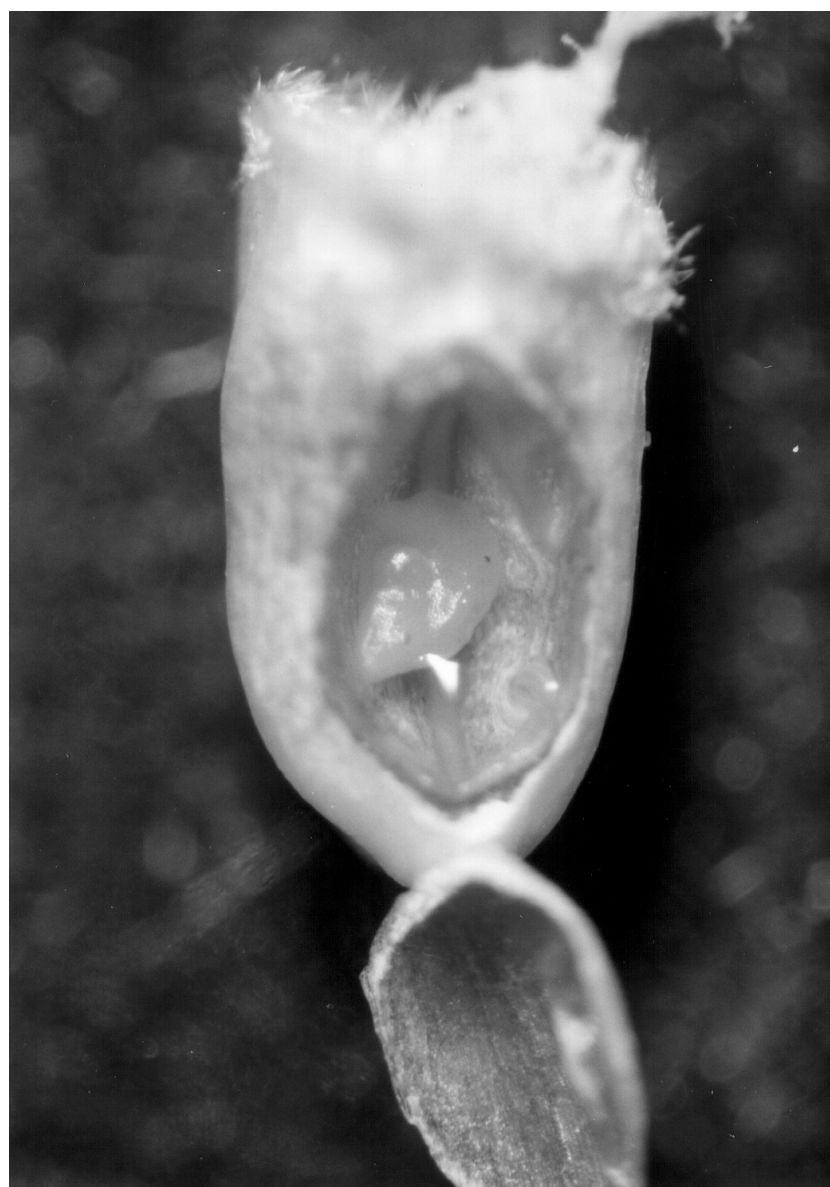

Figure 1 - Embryo formation through wheat x maize hybridization, 14 days after pollination. Note the embryo floating in a liquid not characterized as endosperm.

what lower when compared to results obtained by other authors, possibly because we used a five-times lower concentration of 2,4-D (0.001\%) for spike injection during the hybridization process (Zang et al., 1996; Riera-Lizarazu and Mujeeb-Kazi, 1990; Riera-Lizarazu et al., 1992). Haploid plant production frequencies of $1-4 \%$ have been considered acceptable but with the detached tiller method it could reach as high as 25\% (Riera-Lizarazu et al., 1992).

The procedure using wheat $x$ maize hybrids allows complete homozygosity within one generation and facilitates the somaclonal variant selection process. Gametoclonal variation is known to occur in doubled haploids (Rode et al., 1987; Gallais, 1988; Bjornstad et al., 1993). According to Zang et al. (1996), haploid embryo production frequency and plant regeneration is affected significantly by maize genotypes, but not by wheat genotypes. Although no haploid embryo was produced in cv. 'BR 18', in all the other cultivars and in the somaclones, hybrid embryos and haploids were produced, thereby indicating that the wheat genotype did not affect haploid plant production (Tables II, III and IV). Failure to produce haploid embryos in 'BR 18' was probably due to the low 2,4-D con- centration used in our study. Zang et al. (1996) reported that the concentration of 2,4-D also affected embryo size.

\section{ACKNOWLEDGMENTS}

Research supported by Conselho Nacional de Pesquisa CNPq, Brazil.

\section{RESUMO}

Sete cultivares de trigo possuindo certo nível de resistência a Bipolaris sorokiniana, Magnaporthe grisea, Xanthomonas campestris pv. undulosa (Xcu), foram usadas para variação somaclonal, a fim de induzir um nível maior de resistência. A frequiência de indução de calos variou entre 69,4 e 100 entre as cultivares, enquanto que, a frequiência de regeneração de plantas R1 variou entre 2,7 e 23,1, dependendo da cultivar. A variação para resistência entre as plantas de $\mathrm{R} 2$ foi observada para $B$. sorokiniana e M. grisea, mas não para Xcu. Procurou-se fixar as características de resistência dos somaclones (R3) através de hibridação com milho. A hibridação entre trigo e milho produziu 81 embriões zigotos. Um total de 11.624 flores de somaclones foram polinizadas, das quais $8,4 \%$ produziram embriões haplóides nos sete genótipos de trigo. A frequiência de produção de embriões haplóides variou entre 0 e 25 . A freqüência de plantas haplóides totipotentes variou entre 0 e 66,6. A análise citológica de somaclones demonstrou um número cromossômico constante, conforme observado nos seus genótipos originais de trigos hexaplóides $(2 n=6 x=42)$, enquanto que, as plantas haplóides demonstraram apenas metade dos cromossomos $(n=21)$. A produção de embriões híbridos e plantas haplóides e duplohaplóides foram afetadas pela concentração de 2,4-D, mas não pelo genótipo de trigo.

\section{REFERENCES}

Araujo, L.G., Prabhu, A.S. and Freire A.B. (1995). Variação somaclonal na cultivar de arroz IAC-47 para resistência parcial a brusone. Fitopatol. Bras. 20: 302 (Abstract).

Bjornstad, A., Skinnes, H. and Thoresen, K. (1993). Comparisons between doubled haploid lines produced by anther culture, the Hordeum bulbosum-method and lines produced by single seed descent in barley crosses. Euphytica 66: 135-144.

Comeau, A., Plourde, A.S.T., Pierre, C.A. and Nadeau, P. (1998). Production of doubled haplod wheat lines by wheat x maize hybridization. Genome 30 (Suppl. 1): 482 (Abstract).

De Buyser, J., Lonnet, P., Hertzoc, R. and Hespel, A. (1987). "Florin": A doubled haploid wheat variety developed by the anther culture method. Plant Breed. 98: 53-56.

Gallais, A. (1988). A method of line development using doubled haploids: the single doubled haploid descent recurrent selection. Theor. Appl. Genet. 75: 330-332.

Jahne, A., Becker, D., Brettschneider, R. and Lorz, H. (1994). Regeneration of transgenic, microspore-derived, fertile barley. Theor. Appl. Genet. 89: 525-533.

Laurie, D.A. and Bennett, M.D. (1988). The production of haploid wheat plants from wheat maize crosses. Theor. Appl. Genet. 76: 393-397.

Maddock, S.E., Lancaster, V.A., Risiott, R. and Franklin, J. (1983). Plant regeneration from cultured immature embryos and inflorescences of 25 cultivars of wheat (Triticum aestivum). J. Exp. Bot. 34: 915-926.

Mehta, Y.R. (1981). Conidial production, sporulation period and lesion extension of Helminthosporium sativum on flag leaves of wheat. Pesqui. Agropecu. Bras. 16: 77-79.

Mehta, Y.R. (1996a). Resistência de cultivares de trigo a Xanthomonas 
campestris pv. undulosa medida através da taxa de extensão da lesão. Summa Phytopathol. 22: 205-209.

Mehta, Y.R. (1996b). Variação somaclonal nas plantas de trigo regeneradas através de embriogênese. Fitopatol. Bras. 21: 434 (Abstract).

Mehta, Y.R., Campos, L.A.C. and Guzman, E. (1996). Resistência genética de cultivares de trigo a Bipolaris sorokiniana. Fitopathol. Bras. 21: $455-459$.

Murashige, T. and Skoog, F. (1962). A revised medium for rapid growth and bioassays with tobacco tissue cultures. Physiol. Plant. 15: 473-497.

Prabhu, A.S., Filippi, M.C. and Castro, N. (1992). Pathogenic variation among isolates of Pyricularia oryzae affecting rice, wheat, and grasses in Brazil. Trop. Pest Manage. 38: 367-371.

Riera-Lizarazu, O. and Mujeeb-Kazi, A. (1990). Maize (Zea mays L.) mediated wheat (Triticum aestivum L.) polyhaploid production using various crossing methods. Cereal Res. Commun. 18: 339-343.

Riera-Lizarazu, O., Mujeeb-Kazi, A. and William, M.D.H.M. (1992). Maize (Zea mays L.) mediated polyhaploid production in some Triticeae using a detached tiller method. J. Genet. Breed. 46: 335-346.

Rode, A., Hartmann, C., Benslimane, A., Picard, E. and Quetier, F. (1987) Gametoclonal variation detected in the nuclear ribosomal DNA from doubled haploid lines of a spring wheat (Triticum aestivum L., cv. 'César'). Theor. Appl. Genet. 74: 31-37.

Vasil, I. and Vasil, V. (1986). Regeneration in cereal and other grass species. In: Cell Culture and Somatic Cell Genetics of Plants (Vasil, I. and Vasil, V., eds.). Vol. 3. Praeger Press, New York, pp. 121-150.

Zadoks, J.C. (1972). Reflections on disease resistance in annual crops. In: Biology of Rust Resistance in Forest Trees (Bringham, R.T., Hoff, R.J. and McDonald, G.I., eds.). US Department of Agriculture and Forest Service Miscellaneous Publications No. 1221, Washington, USA, pp. 43-63.

Zhang, J., Friebe, B., Raupp, W.J., Harrison, A.S. and Gill, B.S. (1996). Wheat embryogenesis and haploid production in wheat $\mathrm{x}$ maize hybrids. Euphytica 90: 315-324.

(Received November 25, 1999) 